\title{
A clinical study of a family with Cockayne's syndrome
}

\author{
ROSALYN PROOPS*, A M R TAYLOR†, AND J INSLEY \\ From * the University Department of Clinical Genetics, Birmingham Maternity Hospital; \\ $\dagger$ the Department of Cancer Studies, The Medical School, University of Birmingham; and \\ $\ddagger$ the Infant Development Unit, Birmingham Maternity Hospital, Birmingham
}

SUMmaRY Two sibs with Cockayne's syndrome are described. The recognised cellular sensitivity to $\overrightarrow{\dot{\oplus}}$ ultraviolet light is confirmed. The clinical features in the two children are described and comparisons are made with some forms of xeroderma pigmentosum, a condition in which there is progressive $\infty_{\infty}^{\infty}$ neurological degeneration and cellular sensitivity to ultraviolet irradiation.

In 1936 Cockayne ${ }^{1}$ described two sibs with dwarfism, progressive mental retardation, and erythematous dermatitis, who went on to develop odd facial appearance and visual failure associated with unusual retinal pigment. ${ }^{2}$ Later reports have confirmed that this is a distinct syndrome inherited in an autosomal recessive manner, although there are fewer than $\mathbf{4 0}$ cases reported.

Recent interest in Cockayne's syndrome has been renewed since cultured skin fibroblasts from these patients were shown to be unusually sensitive to killing by ultraviolet light. ${ }^{3}{ }^{4}$ At least three syndromes are known to demonstrate an unusual clinical sensitivity to one of a number of environmental agents. These are xeroderma pigmentosum (UV), Cockayne's syndrome (UV), and ataxia telangiectasia (ionising radiation). Cultured cells from patients with xeroderma pigmentosum and Cockayne's syndrome are sensitive to UV light and to specific chemicals, producing similar nuclear abnormalities. ${ }^{5-7}$ Cells from patients with ataxia telangiectasia are unusually sensitive to ionising radiation and the radiomimetic chemical bleomycin. ${ }^{89}$ In addition, cells cultured from patients with Fanconi's anaemia are sensitive to DNA-DNA cross-linking agents, ${ }^{10}$ and Gianelli et al ${ }^{11}$ have reported that cultured cells from patients with Bloom's syndrome are UV sensitive, but this is not a consistent finding. ${ }^{12}$ Particular enzyme defects in DNA repair have been reported for both xeroderma pigmentosum ${ }^{13}$ and ataxia telangiectasia ${ }^{\mathbf{1 4} 15}$ which would account for the in vitro sensitivity and the clinical manifestations, but these studies are not complete.

This paper describes a family where two of the three children have Cockayne's syndrome. The 을 association between this progressive neurological $\stackrel{\infty}{\rightarrow}$ disease and sensitivity to UV light is presented and $\vec{\bullet}$ discussed.

\section{Case reports}

The first and third children in this sibship who have Cockayne's syndrome are described below. The second child is normal and healthy as are both parents. There is no evidence of consanguinity.

CASE 1

The girl was born after an uneventful pregnancy at term weighing $2.4 \mathrm{~kg}(<10$ th centile). The neonatal period was complicated by slow weight gain and a recurrent erythematous desquamating rash on her face and hands which was particularly obvious after exposure to sunlight. Her growth and development continued normally until the age of 2 years, but by 3 years of age she had ceased to grow: weight $8 \mathrm{~kg}$, height $70 \mathrm{~cm}$, and head circumference $42 \mathrm{~cm}$. A $\frac{7}{0}$ progressive neurological abnormality was first suspected because of her gradual deterioration in $N$ development and the onset of minimal generalised $N$ spasticity. By 9 years, she could walk with support $\mathcal{N}$ but still needed help feeding and dressing. Despite $\omega$ good comprehension, her speech was limited to single words uttered in a shrill tremulous tone. She $\stackrel{\varrho}{\subset}$ developed photophobia and a moderate sensori- $\mathbb{D}$ neural hearing loss. Her appearance was odd; she $\stackrel{+}{+}$ was dwarfed (height $92 \mathrm{~cm}$, weight $9.2 \mathrm{~kg}$ ) and microcephalic (head circumference $43 \mathrm{~cm}$ ). She had marked $\frac{0}{\mathbb{D}}$ loss of facial subcutaneous tissue, sunken eyes, and a $\frac{\mathcal{O}}{\mathbb{Q}}$

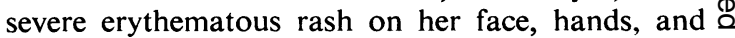


lower legs. Her hair was fine and sparse, her teeth were carious, and her nails dystrophic. The peripheral circulation was poor and her hands and feet appeared unusually large in proportion to her short trunk and the wasting of her limbs. The spastic quadriplegia was of moderate severity associated with extensor plantor responses, but there were depressed deep tendon reflexes and limb and truncal ataxia. Flexion deformities of her elbows, knees, and hips were present with a mild scoliosis. Progressive deterioration occurred over the following 4 years, resulting in loss of independent mobility, loss of speech, incontinence, and increasing skeletal deformities. She developed bilateral optic atrophy and 'salt and pepper' retinal pigmentation. She died aged 13 years from bronchopneumonia (fig 1a).

\section{CASE 2}

The younger brother had a normal perinatal history, birthweight $3 \mathrm{~kg}$. By 6 months of age the mother realised that he was similarly affected; his weight gain was poor and he had persistent photosensitive skin rashes and early facial changes.

When seen at 5 years old, he cruised around the furniture, helped with feeding and dressing, and said single words. Despite his low level of motor and manipulative skills, his social responses were comparable to a 3-year-old. He was dwarfed (height $84.5 \mathrm{~cm}$, crown-rump $48 \mathrm{~cm}$, weight $9.4 \mathrm{~kg}$; below 3rd centile) and microcephalic (head circumference

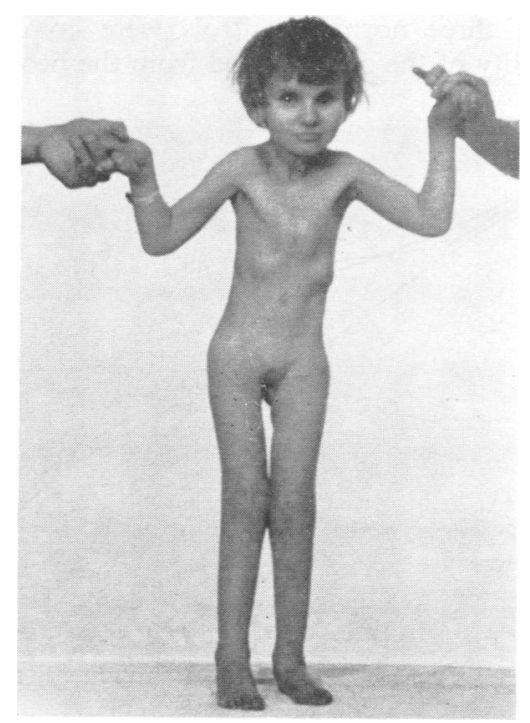

FIG 1 (a) Case 1 aged 11 years.

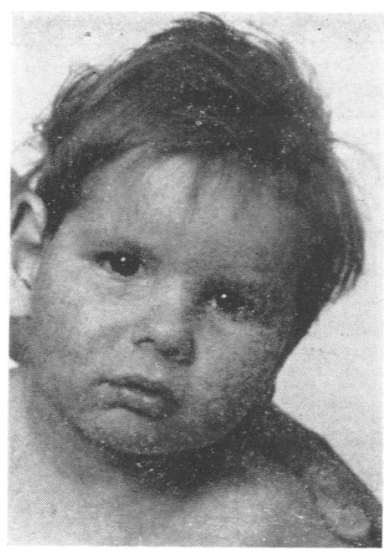

FIG 1 (b) Case 2 aged 2 years.

$44 \mathrm{~cm}$ ). His appearance was very similar to his sister's at the same age, but with signs of a peripheral neuropathy. He had no cerebellar involvement (fig 1b).

\section{Investigations}

\section{RADIOLOGY}

In both children the bone age was equivalent to the chronological age.

The skull $x$-ray of case 1 at 9 years showed calcification in the basal ganglia. The long bones were slender with enlarged metaphyses and epiphyses and the pelvic ilia were hypoplastic. The vertebral bodies were narrow with translucent areas in the lateral borders.

The skeletal survey of case 2 at 5 years was normal.

\section{NEUROLOGICAL STUDIES}

Nerve conduction studies in both children showed reduced motor and sensory velocities $(20$ to $25 \mathrm{~m} / \mathrm{s}$; normal $>50 \mathrm{~m} / \mathrm{s})$. Electroencephalogram in both children showed low amplitude, non-specific changes.

\section{CHROMOSOME ANALYSIS}

Heparinised blood was obtained from case 2, his unaffected brother, and both parents. A total of $0.4 \mathrm{ml}$ whole blood was cultured in $4.0 \mathrm{ml}$ Ham's F10 medium with $0.5 \mathrm{ml}$ bovine serum, penicillin (100 IU ml-1) and streptomycin $\left(100 \mu \mathrm{g} \mathrm{ml}^{-1}\right)$. Cultures were fixed at 48 hours.

Orcein stained preparations were analysed. The karyotypes of the father, unaffected brother, and case 2 were all $46, X Y$, and that of the mother $46, X X$. No increased levels of spontaneous chromosome damage were observed (table 1). 
TABLE 1 Analysis of spontaneous chromosome damage in lymphocytes from the patient, his brother, and parents

\begin{tabular}{llllllll}
\hline Patient & $\begin{array}{l}\text { Relation to } \\
\text { patient }\end{array}$ & $\begin{array}{l}\text { No of cells } \\
\text { analysed }\end{array}$ & No of $r$ & No of dic & No of $f$ & No of ctg & No of ctb \\
\hline ME & Patient & 50 & 0 & 0 & 0 & 0 & 0 \\
JE & Father & 20 & 0 & 0 & 0 & 0 \\
LE & Mother & 20 & 0 & 0 & 0 & 0 & 0 \\
NE & Brother & 20 & 0 & 1 & 0 & 0 \\
\hline
\end{tabular}

$\mathbf{r}=$ rings

dic $=$ dicentrics

$\mathbf{f}=$ fragments

ctg $=$ chromatid gaps

$\mathrm{ctb}=$ chromatid breaks

Colony forming ability after irradiation by either ultraviolet light or $x$-rays

\section{METHOD}

Fibroblast cultures were derived from full thickness pinch skin biopsies. Small skin fragments were placed under coverslips in petri dishes containing Dulbecco's modified Eagle's medium supplemented with $10 \%$ fetal calf serum, penicillin $\left(100 \mathrm{IU} \mathrm{ml}^{-1}\right)$, and streptomycin $\left(100 \mu \mathrm{g} \mathrm{ml}^{-1}\right)$.

After 3 to 4 weeks, sufficient cells had grown out to permit the first trypsinisation.

For UV survival curves, cells were plated in appropriate numbers into petri dishes containing a feeder layer of $6 \times 10^{4}$ cells (derived from the same cultures and irradiated with $3.5 \mathrm{krad}{ }^{60} \mathrm{Co} \gamma$-rays).

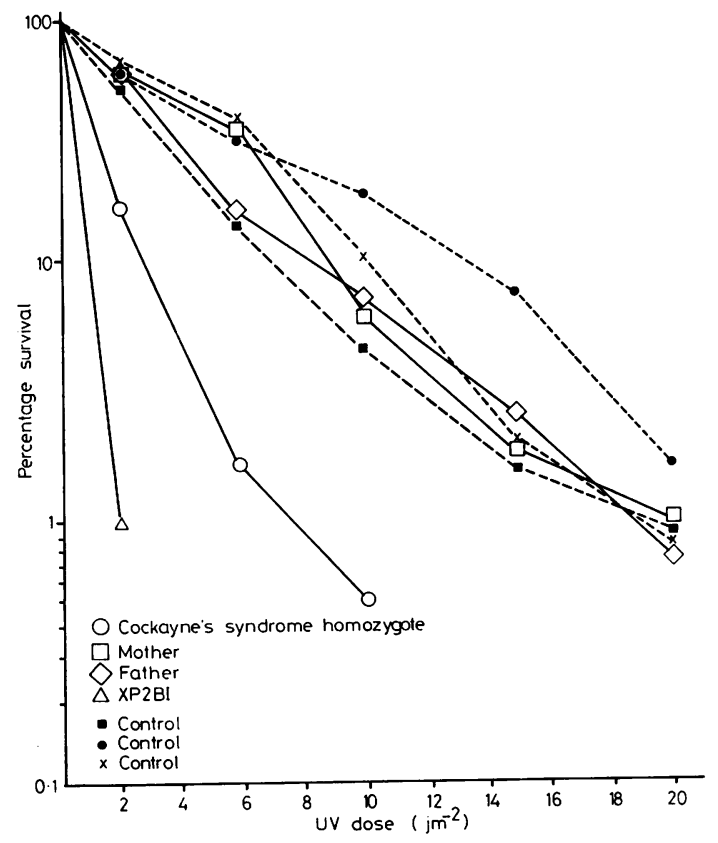

FIG 2 Sensitivity of cells to UV irradiation
The cells were incubated for 24 hours at $37^{\circ}$ to permit attachment to the plastic surface. The culture medium $\vec{\infty}$ was replaced with $5 \mathrm{ml}$ Dulbecco A buffer, the covers were removed, and the cells exposed for various times to UV light (Hanovia lamp, predominant wave-

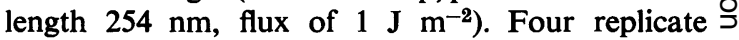
dishes were used at each UV dose. After irradiation the buffer was removed, replaced with complete medium, and the cells incubated for 14 to 21 days with a change of medium each week.

In the $x$-ray experiment the cells were diluted, $\overrightarrow{0}$ suspended in glass vessels, and irradiated with a $\stackrel{\infty}{-}$ dose of 100 to 500 rad (Pantak $x$-ray set, $245 \mathrm{KeV}$, $12 \mathrm{~mA}$, HVL $0.1 \mathrm{~mm} \mathrm{Cu}$, FSD $30 \mathrm{~cm}$, dose rate $100 \mathrm{rad} \mathrm{min}^{-1}$ ). The cells were plated on to $\gamma$-irradiated feeder layers and subsequently treated as in the UV experiment.

RESULTS

Fig 2 shows that after UV irradiation the colony forming abilities of cells derived from the two parents and the three normal controls were comparable. The ability of the cells derived from the proband to

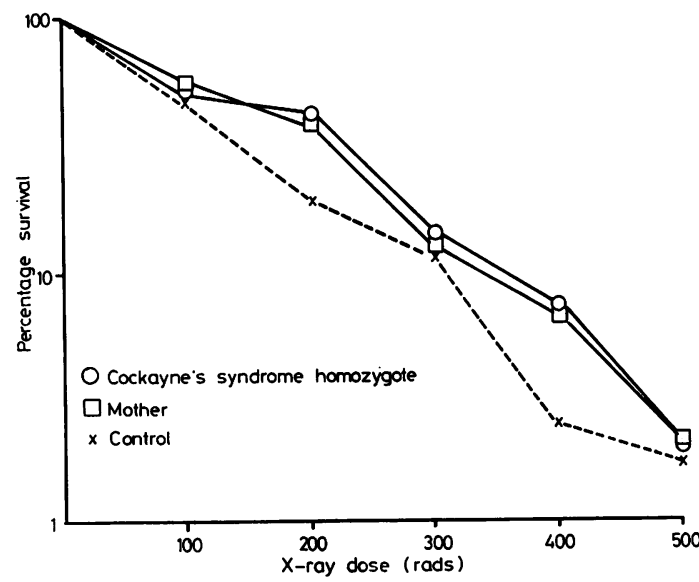

FIG 3 Sensitivity of cells to $X$ irradiation 
form colonies was severely diminished, although this did not reach the low level seen in the positive control, a $\mathrm{G}$ group xeroderma pigmentosum patient (cell line XP2BI). After $\mathrm{X}$ irradiation the colony forming abilities of cells derived from the affected child, his mother, and a normal control were the same (fig 3).

\section{Discussion}

Cockayne's syndrome (CS) is a rare progressive disease of childhood, almost certainly of genetic origin. Parental consanguinity has been described in four cases and this family is the seventh reported case of CS occurring in sibs, which strongly supports autosomal recessive inheritance. ${ }^{16}$

The clinical features are constant, but vary in severity. Photosensitivity often precedes the profound failure to thrive and delayed development. The acute sun sensitivity in infancy can be severe, resulting in bullae, desquamation, and atrophic areas occurring on unprotected skin. By 4 years the characteristic facial appearance is evident with dwarfism and microcephaly. The trunk is short and wasting of the limb muscles exaggerates the apparently large extremeties. Slow developmental progress occurs but the level of skills attained is often scattered. ${ }^{17}$ Early sensorineural hearing loss is common, but visual deterioration (optic atrophy and retinal pigmentation) is a late feature. By 10 to 20 years, spasticity and ataxia develop and skills are lost. In some cases this may be because of the onset of normal pressure hydrocephalus. ${ }^{18}$ Involvement of the anterior horn cells and delayed nerve conduction velocities $^{19}$ provide further evidence for the widespread neurological impairment. Premature ageing occurs, particularly in the integumentae, and atherosclerotic changes are found in the retinal vessels and also with the onset of hypertension. ${ }^{17}$ Senile cataracts may develop. The boys are often cryptorchid; in both sexes puberty is delayed or fails to occur because of hypothalmic dysfunction and hypoplasia of the gonads. Recurrent bacterial infections are common; most children succumb by the second decade.

Pathological studies demonstrate diffuse but extensive demyelination in the central and peripheral nervous system..$^{20}$ Pericapillary calcification in the cortex and basal ganglia occurs early. Severe neuronal loss, notably in the cerebral cortex and cerebellum, but also in the spinal cord, is associated with lipofuscin accumulation in the remaining neurones.

These findings, which are compatible with the physiological changes of ageing, suggest that premature senility is a facet of CS. ${ }^{21}$ The clinical features are related to the cerebral degeneration and the demyelination, but the dwarfism, bone changes, and photosensitivity distinguish this syndrome from other progressive neurological diseases.

UV light sensitivity has been described in cell strains from 12 patients with Cockayne's syndrome ${ }^{4722}$ and possibly seven other cases. ${ }^{23}$ The case presented here, we believe, is the first Cockayne's patient in the UK shown to have an unusual UV sensitivity. Cells from these parents (obligate heterozygotes) are no more sensitive than cells from normal controls. This result is in agreement with Marshall et $a l^{22}$ but contrary to that reported by Wade and Chu, ${ }^{7}$ who demonstrated an intermediate response in the heterozygotes. In this study a dose of approximately $3 \mathrm{Jm}^{-2}$ was required to reduce the cell survival of the normal controls and the heterozygotes to $50 \%$, but for the proband's cells the same reduction in survival was achieved with a dose of approximately $1 \mathrm{Jm}^{-2}$. A further indicator of cell sensitivity is demonstrated by the pattern of DNA synthesis. In normal cells and Cockayne's heterozygotes UV light causes a depression in the rate of DNA replicative synthesis followed by recovery 5 to 8 hours after irradiation. In the Cockayne's homozygotes the initial depression is identical but there is no subsequent recovery. ${ }^{24}$

Xeroderma pigmentosum is the other well documented disorder demonstrating an unusual sensitivity to UV light. There are several similarities between Cockayne's syndrome and the progressive neurological disorder seen in some patients with xeroderma pigmentosum ${ }^{25}$ (table 2 ). The severe disorder features progressive microcephaly, progressive dementia, spasticity, ataxia, and choreoathetosis. Absence of deep tendon reflexes is an early sign of neurological impairment. This is accompanied by normal motor nerve conduction times, but a neuropathic electromyogram led Robbins et $a l^{26}$ to conclude that there is neuronal degeneration of peripheral nerves. Short stature, delayed puberty, and nerve deafness are other features common to both diseases.

In xeroderma pigmentosum the clinical manifestations of UV sensitivity are erythema and desquamation, leading to bullae, hypopigmented atrophic skin, and keratoses. Basal and squamous cell carcinomas develop during childhood and adolescence and half the patients develop malignant melanomas. The eyes are also sensitive to sunlight, with the development of photophobia, conjunctivitis, atrophic lids, and keratitis. Skin tumours and external ocular abnormalities have not been reported in patients with Cockayne's syndrome.

In both conditions the pattern of cell survival following UV and ionising irradiation is similar. UV 
TABLE 2 The clinical features of Cockayne's syndrome and xeroderma pigmentosum compared

\begin{tabular}{|c|c|c|}
\hline & Xeroderma pigmentosum & Cockayne's syndrome \\
\hline Inheritance & Autosomal recessive & Autosomal recessive \\
\hline Characteristic facies & 一 & ++ \\
\hline Neurological abnormalities & $\begin{array}{l}40 \% \\
\text { Complementation group } A(B, D)\end{array}$ & $100 \%$ \\
\hline Progressive mental retardation & Early & Early \\
\hline Microcephaly & + & + \\
\hline Spasticity with extensor plantar responses & + & + \\
\hline Choreoathetosis & + & + \\
\hline Absent tendon reflexes & + & + \\
\hline Sensorineural hearing loss & + & + \\
\hline Visual failure & - & Optic atrophy/retinal dystrophy \\
\hline Electroencephalography & Excess slow wave activity & Low amplitude \\
\hline Electromyography & Neuropathic & ? \\
\hline Nerve conduction velocity & Normal & Delayed \\
\hline Anterior horn cell involvement & + & + \\
\hline Peripheral neuropathy & - & + \\
\hline Erythema, bullae, desquamation, atrophy & ++ & + \\
\hline Pigmentary changes & + & - \\
\hline External ocular abnormalities & ++ & - \\
\hline Tumours & $90 \%$ & - \\
\hline Basal and squamous cell carcinoma & $50 \%$ by 10 yr & - \\
\hline Malignant melanoma & $50 \%$ by 30 yr & - \\
\hline Stature & Normal $\rightarrow$ dwarfed & Dwarfed \\
\hline Delayed/failed puberty & + & + \\
\hline Evidence of ageing & - & ++ \\
\hline \multicolumn{3}{|l|}{ Cell survival } \\
\hline Exposure to UV irradiation & Decreased $t+$ & Decreased + \\
\hline Exposure to $\gamma$ irradiation & Normal & Normal \\
\hline \multicolumn{3}{|l|}{ Chromosome abnormalities } \\
\hline Spontaneous & - & - \\
\hline Exposure to UV irradiation & + & $?$ \\
\hline Exposure to $\gamma$ irradiation & - & - \\
\hline \multicolumn{3}{|l|}{ Pathology } \\
\hline Neuronal loss: cerebral and cerebellum & ++ & ++ \\
\hline
\end{tabular}

irradiation of cells derived from Cockayne's syndrome and from xeroderma pigmentosum homozygotes produces a marked depression in colony forming ability, whereas the response to $\gamma$ irradiation is comparable to normal control cell lines. In both conditions the heterozygotes appear indistinguishable from controls.

In these two conditions there are both similarities and differences in the point of action of the enzyme(s) involved in UV damage. Cells from xeroderma pigmentosum patients are either unable to excise UV induced pyrimidine dimers as efficiently as normals (complementation groups A to G), or are deficient in bypass repair (xeroderma pigmentosum variants). Cockayne's patients are proficient in both these mechanisms. ${ }^{24}$ However, cells from Cockayne's and xeroderma pigmentosum patients are unable to repair 'long patch' damage caused by either the chemicals $\mathrm{N}$-acetoxyaminofluorene and 4 nitroquinoline-1-oxide (NQO) or UV light. ${ }^{7}$ A further measure of ultraviolet sensitivity is an increase in the sister chromatid exchange frequency (SCE). In xeroderma pigmentosum the spontaneous frequency of SCEs is normal, but there is a large increase in SCEs after treatment with UV or NQO. ${ }^{27}$ A similar response has been demonstrated with Cockayne's syndrome fibroblasts. ${ }^{22}$ This has not been confirmed using lymphoid cell lines. ${ }^{28}$ Neither Cockayne's syndrome nor xeroderma pigmentosum are associated with constitutional chromosome abnormalities, nor is there an increased frequency of unstable aberrations or stable rearrangements, as found in ataxia telangiectasia, Fanconi's anaemia, and Bloom's syndrome.

Cockayne's syndrome is characterised by wide- $\stackrel{\Omega}{\circ}$ spread progressive neurological abnormalities and an $N$ unusual sensitivity to sunlight. In xeroderma pig- N mentosum, UV sensitivity is the primary clinical 0 manifestation, frequently associated with the development of UV induced tumours. It is tempting

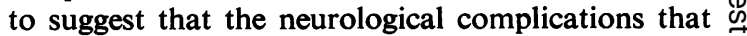
occur in 20 to $30 \%$ of these patients are related to UV radiation but, at present, the evidence for this simply stems from in vitro experiments on fibroblasts (complementation groups $\mathbf{A}(\mathbf{B}+\mathbf{D})$ )).

In Cockayne's syndrome, in vitro UV sensitivity is 
confirmed but, as in xeroderma pigmentosum, the underlying mechanism is not known.

A M R Taylor wishes to thank the Cancer Research Campaign for continued support. We would also like to thank Dr R Astley for the radiological reports, Miss G Duckworth for technical assistance, and Miss J Hodgetts for secretarial assistance.

\section{References}

1 Cockayne EA. Dwarfism with retinal atrophy and deafness. Arch Dis Child 1936;11:1-8.

2 Cockayne EA. Dwarfism with retinal atrophy and deafness. Arch Dis Child 1946;21:52-4.

3 Schmickel RD, Chu EHY, Trosko JE. The definition of a cellular defect in two patients with Cockayne's syndrome. Pediatr Res 1975;9:317.

4 Schmickel RD, Chu EHY, Trosko JE, Chang CC. Cockayne syndrome: a cellular sensitivity to ultraviolet light. Pediatrics 1977;60:135-9.

5 Cleaver JE. Defective repair replication of DNA in xeroderma pigmentosum. Nature 1968;218:652-6.

6 Cleaver JE. Repair processes for photochemical damage in mammalian cells. Adv Rad Biol 1974;4:1-75.

7 Wade MH, Chu EHY. Effects of DNA damaging agents on cultured fibroblasts derived from patients with Cockayne syndrome. In: Hanawalt PC, Friedberg EC, Fox CF, eds. DNA repair mechanisms. New York: Academic Press, 1978:667-70.

8 Taylor AMR, Harnden DG, Arlett CF, et al. Ataxia telangiectasia: a human mutation with abnormal radiation sensitivity. Nature 1975;258:427-9.

9 Taylor AMR, Rosney CM, Campbell JB. Unusual sensitivity of ataxia telangiectasia cells to bleomycin. Cancer Res 1979;39:1046-50.

10 Sasaki MS, Tonomura A. A high susceptibility of Fanconi's anaemia to chromosome breakage by crosslinking agents. Cancer Res 1973;33:1829-36.

11 Gianelli F, Benson PF, Pawsey SA, Polani PE. Ultraviolet light sensitivity and delayed DNA chain maturation in Bloom's syndrome fibroblasts. Nature 1977;265:466-9.

12 Krepinsky AB, Rainbow AJ, Heddle JA. Studies on the ultraviolet light sensitivity of Bloom's syndrome fibroblasts. Mutat Res 1980;69:357-68.

13 Strauss B, Altamirano M, Bose K, Sklar R, Tatsumi K. Carcinogen-induced damage to DNA. In: Griffin AC, Shaw CR, eds. Carcinogens: identification and mechanisms of action. New York: Raven Press, 1979:229-50.

14 Paterson MC, Smith BP, Lohman PHM, Anderson AK, Fishman L. Defective excision repair of gamma raydamaged DNA in human (ataxia telangiectasia) fibroblasts. Nature 1976;260:444-6.
15 Inoue $\mathrm{T}$, Hirano $\mathrm{K}$, Yokoiyama A, Kada $\mathrm{T}$, Kato $\mathrm{H}$. DNA repair enzymes in ataxia telangiectasia and Bloom's syndrome fibroblasts. Biochim Biophys Acta 1977;479: 497-500.

16 Sugarman GI, Landing BH, Reed BR. Cockayne syndrome: clinical study of two patients and neuropathological findings in one. Clin Pediatr 1977;16:225-32.

17 Neill CA, Dingwall MD. A syndrome resembling progeria: review of two cases. Arch Dis Child 1950;25:213-21.

18 Brumback RA, Yoder FW, Andrews AD, Peck GL, Robbins JH. Normal pressure hydrocephalus: recognition and relationship to neurological abnormalities in Cockayne's syndrome. Aich Neurol $1978 ; 35: 337-45$.

19 Moosa A, Dubowitz V. Peripheral neuropathy in Cockayne's syndrome. Arch Dis Child 1970;45:674-7.

20 Norman RM, Tingey AH. Syndrome of micrencephaly, striocerebellar calcifications and leucodystrophy. $J$ Neurol Neurosurg Psychiatry 1966;29:157-63.

21 Moosy J. The neuropathology of Cockayne's syndrome. $J$ Neuropath Exp Neurol 1967;26:654-60.

22 Marshall RR, Arlett CF, Harcourt SA, Broughton BA. Increased sensitivity of cell strains from Cockayne's syndrome to sister-chromatid-exchange induction and cell killing by UV light. Mutat Res 1980;69:107-12.

23 Andrews AD, Barrett SF, Yoder FW, Robbins JH. Cockayne's syndrome fibroblasts have increased sensitivity to ultraviolet light but normal rates of unscheduled DNA synthesis. J Invest Dermatol 1978;70:237-9.

24 Lehmann AR, Kirk-Bell S, Mayne L. Abnormal kinetics of DNA synthesis in ultraviolet light-irradiated cells from patient with Cockayne's syndrome. Cancer Res 1979;39: 4237-41.

25 de Sanctis C, Cacchione A. L'iodiozia xerodermia. Rev Sper Freniatr 1932;56:269-92.

26 Robbins JH, Kraemer KH, Lutzner MA, Festoff BW, Coon HG. Xeroderma pigmentosum: an inherited disease with sun-sensitivity, multiple cutaneous neoplasms and abnormal DNA repair. Ann Intern Med 1974;80: 221-48.

27 Kraemer KH. Progressive degenerative diseases assocated with defective DNA repair: xeroderma pigmentosum and ataxia telangiectasia. In: Nichols WW, Murphy DG, eds. DNA repair processes. Florida: Symposia Specialists, 1977:37-73.

28 Cheng WS, Tavone RE, Andrews AD, Whang-Peng JS, Robbins JH. Ultraviolet light-induced sister chromatid exchanges in xeroderma pigmentosum and Cockayne's syndrome lymphocyte cell lines. Cancer Res 1978;38: 1601-9.

Requests for reprints to Dr J Insley, Department of Clinical Genetics, Infant Development Unit, Birmingham Maternity Hospital, Birmingham B15 2TG. 